\title{
VERSITA
}

\section{Risks and Challenges \\ Introduction to Social Change Review Special Issue}

\author{
Burkhard Bierhoff ${ }^{1}$, Hans-Peter Michels ${ }^{1}{ }^{*}$ \\ ${ }^{1}$ Hochschule Lausitz - University of Applied Sciences, Fakultät für Wirtschafts- und Sozialwissenschaften, Musikpädagogik, 47 \\ Lipezker Str., 03048 Cottbus, Germany
}

The next two issues of the Social Change Review cover the current era by a series of articles. We live in a period of risks, dangers, and challenges. A general theory of the era with solutions for all problems does not exist. We are looking for a new form of social organisation, in order to respond to threats and to safeguard our future. We need new attitudes in shaping our lifestyles, but also new forms of democratic participation in community life. We need a secure peaceful world, in which people and nations are not in conflict with each other. At the end of the Second Modernity, we need new waves of Enlightenment, with global consequences for the urgent problems of environmental protection, food production, and consumption.

First of all, we need sociological imagination and the courage to rethink society and human life. We need social diagnoses that describe the current situation, without reservations and make it understandable, providing a realistic examination of facts.

The contributions included in these two volumes are not committed to any scientific school, but to an exploratory attitude that goes beyond deductive empiricism, and considers the interrelation between reality and knowledge in constructivist sense - and it is otherwise committed to a critical and humanistic approach, that include empirical social research. This position is an opportunity to share, but it is not intended to allocate the authors to a position to which they do not agree.

The contributions that are published in this volume and the following one cover a wide range of content: the interpretation of the current

\footnotetext{
* Contact address: Burkhard.Bierhoff@hs-lausitz.de (B. Bierhoff) 
geopolitical situation, criticism of capitalism and libertarian ideology, the fusion of economic and political power, and the crisis of governance. Other contributions deal with poverty and precariousness, material prosperity, consumerism, and wealth. Risks are considered but creative potentials in the life of western world. In the present era, people faced with a series of decisions concerning their ways of life, their lifestyles depending on the social importance of work and consumption, social participation and the configuration of international relations.

The first article presented in this volume comes from Amitai Etzioni and examines The Domestic Sources of Global Adhocracy. It is an attempt to an overall interpretation of the world's political situation. This is evident not only in crises of financial, economic and military nature; the main crisis, facing important international protagonists, is an institutional crisis; more precisely, it affects internal relations and is a crisis of governance. This is visible in the decline of government competence and diminishing legitimacy in the perception of the general public. The Governance model as interpreted by Etzioni does not assume that the capitalism is the main problem, but that its unleashing has been made by the withdrawal of the state, with the pursuit of deregulation and strict adherence to liberal ideas. By the fusion of economic and political centres of power, the political system has been undermined by economic interests. There are also shifts of power in the international arena that will lead - primarily with regard to China - to new imbalances, with a need for regulation, which - in the best scenario will not lead to global armed conflicts, as was the case during the Cold War era.

In his contribution, Amitai Etzioni declares that the present political crisis which has included all the important international participants is neither of a finance-economical nature nor of military provenance, but it is based on insufficient governmental activity, which leads to global regulation deficits that are connected to the flexibility of organisations and to ad hoc decisions. Etzioni describes these structural facts with the concept of adhocracy. Less domestic order is accompanied by more adhocracy. There is no evidence in sight of an end to the institutional crisis. Etzioni uses the model of Governance as a basis to evaluate different developments and changes at international, national and community levels. 
Among others, Etzioni has pointed out that there is an undermining of the social contract by merging economic and political interests and increasing social inequalities. Other unfavourable factors are general loss of values, with consequences for social integration, as well as economic and political decisions, which are focused on short-term benefits, instead of public welfare and sustainable resource policy. In addition, neoliberal ideas have spread and are used to preserve the power of economic actors, but they weaken the cohesion in communities.

In international context, there are not only frictions among cultural trends, but also an increase in the loss of cultural identities. The weakness of the one is confronted with the strength of the other. The international balance of forces between China, the USA and the EU is changing. China seems to be on the way of the leading superpower worldwide.

In his contribution to the Landnahme concept, under the title Finance Capitalism, Landnahme and Discriminating Precariousness, Klaus Dörre presents his capitalism-criticising approach, with which he describes developments and effects of capitalism since the 1970s. The concept of Landnahme is, among others, stimulated by Karl Marx and Rosa Luxemburg. Unlike the English term (land grabbing or acquisition of land) it is not only about the occupation and appropriation of foreign country and ground (external acquisition of land), but also about the occupation of the 'internal territory' of the human productive forces. Dörre describes Landnahme as the expansion of the capitalist mode of production, to inside and outside. Colonisation strategies are therefore supporting capitalism, by making available the material bases of nature and environment, as well as moulding the forces and abilities of man for the purposes of the capitalist mode of production and economic activities. With this opinion, the capitalism is not restricted to the system of economy, but it is extended to all areas of society and subjugates them to its dynamics. This dynamism consists of continuously integrating people, as social actors in these processes of Landnahme. This happens, for instance, by education and the utilisation of the existing structures in the environment.

At the end of the full-time employment-society, the consequences of these developments are accompanied by a special explosive effect, which leads to the situation that outsourced workers, who are separated from 
working life and become precarious. The social protections that are created by 'prospering welfare capitalism' are taken back gradually or are annulled. With the increase in the precarious employer-employee relationships in nearly all social strata, existential fears are increasing and putting pressure on people. The precariousness of work and employment is evaluated by Dörre, as a central social question of the $21^{\text {st }}$ century. The starting-points for the 'work on the social' are also present.

We consider that the contributions of Amitai Etzioni and Klaus Dörre will very likely stimulate the discussions about the current stage of the development of capitalism, as well as the national and international consequences accompanying by it. The search for a new organisation of social life in the world, with basic social options and new types of government can be regarded as a challenge for social movements, national and international actors.

Alban Knecht, who refers to the capability approach of Amartya Sen in Understanding and Fighting Poverty, as well as to other similar theories, starts out from a complementary approach. He evaluates several theories of poverty, in particular the capability approach, the welfare regime approach, the social investment approach, and a new resource theory. These approaches focus on different areas of society, that are mainly comprised of the physical features of the welfare institutions, the importance of human capital and the relationship between poverty and health.

Knecht provides a combinatorial approach, in order to better understand the conditions and consequences of poverty. His aim is to reduce poverty by selective social policies. He emphasises on social work as a strategy for intervention to strengthen social and psychological resources, and in addition supporting social policies to distribute monetary resources, and to create a positive climate in the community.

The author always keeps the differences and mutual supplements in mind, which offer these approaches in their orientations at the macro level and the micro level, and provide a very interesting synopsis of social problems, skills and perspectives to solving problems.

In a further article on The Domestication of Luxury in Social Theory, Dominik Schrage is concerned with luxuries consumption. This consumption has played, since at least the $19^{\text {th }}$ century, an important role in 
society, because it enabled a comparison of status on the basis of consumption of luxury goods. With the disposal over luxury goods, social exclusivity could be signalled and social status was reproduced. On luxury consumption, social disparities became visible, too.

Schrage mainly cited the sociologists Werner Sombart, Georg Simmel and Thorstein Veblen, who deal with different aspects of consumption in capitalist societies, in the first half of the 20th century, as well as David Riesman, John Kenneth Galbraith and Pierre Bourdieu, in the second half of the $20^{\text {th }}$ century.

With the rise of the bourgeoisie in the $18^{\text {th }}$ century, the category of luxury consumers expanded, the increasing consumption of goods signalled social mobility, without imitating an extravagant lifestyle. In any case, the luxury consumption made visible the order of prestige in society. This order levelled out from the middle of the $20^{\text {th }}$ century, so that luxury consumption became somehow invisible along with the social positions corresponding to it and was replaced by finer distinctions. The mechanisms of imitation and distinction also connected people from different social strata and classes in consumption.

Luxury consumption is assessed by Schrage as an important aspect in the development of modern society. The shifts in the semantics of luxury are considered as indicators of social change. With the differentiation into a sphere of production and consumption, modern society becomes increasingly describable as a consumer society, in which the improvement in the pleasure of living is performed by the consumption of goods; this consumption carries the integration into the social hierarchy of society, and at the same time, it also signals the capability for 'upward social mobility'.

Overall, Schrage's remarks can be understood as a contribution to the elucidation of contemporary society, with which he points out the social function of luxury consumption, for the development of the consumer society, in which social integration is essentially based on the consumer's role.

The four authors have worked on different levels of reality and problem areas that are particularly important in the contemporary sociology. In an overall view, the basic lines of a committed social diagnosis become visible, which has to do with different social problems of national, 
international, cultural and biographical backgrounds, and among other things, by globalisation, demographic changes, shifts in the balance of power and increasing extremist tendencies. In the next volume of the SCR, further contributions will complete the social diagnosis of the current era. 